\title{
Sedimentology and ichnology of Neogene Coastal Swamp deposits in the Niger Delta Basin, Nigeria
}

\author{
Sunny C. Ezeh ${ }^{1 *}$, Wilfred A. Mode ${ }^{1}$, Berti M. Ozumba² \& Nura A. Yelwa ${ }^{3}$ \\ ${ }^{1}$ Department of Geology, University of Nigeria, Nsukka, Enugu State, Nigeria \\ ${ }^{2}$ Formerly Shell Petroleum Development Company, Port Harcourt, Rivers State, Nigeria \\ ${ }^{3}$ Department of Geology, UsmanuDanfodiyo University, Sokoto State, Nigeria \\ *corresponding author: ezeh.sunnyc@gmail.com
}

\begin{abstract}
Often analyses of depositional environments from sparse data result in poor interpretation, especially in multipartite depositional settings such as the Niger Delta. For instance, differentiating channel sandstones, heteroliths and mudstones within proximal environments from those of distal facies is difficult if interpretations rely solely on well log signatures. Therefore, in order to achieve an effective and efficient interpretation of the depositional conditions of a given unit, integrated tools must be applied such as matching core descriptions with wireline log signature. In the present paper cores of three wells from the Coastal Swamp depositional belt of the Niger Delta are examined in order to achieve full understanding of the depositional environments. The well sections comprise cross-bedded sandstones, heteroliths (coastal and lower shoreface) and mudstones that were laid down in wave, river and tidal processes. Interpretations were made from each data set comprising gamma ray logs, described sedimentological cores showing sedimentary features and ichnological characteristics; these were integrated to define the depositional settings. Some portions from one of the well sections reveal a blocky gamma ray well log signature instead of a coarsening-upward trend that characterises a shoreface setting while in other wells the signatures for heteroliths at some sections are bell blocky in shaped rather than serrated. Besides, heteroliths and mudstones within the proximal facies and those of distal facies were difficult to distinguish solely on well log signatures. However, interpretation based on sedimentology and ichnology of cores from these facies was used to correct these inconsistencies. It follows that depositional environment interpretation (especially in multifarious depositional environments such as the Niger Delta) should ideally be made together with other raw data for accuracy and those based solely on well log signatures should be treated with caution.
\end{abstract}

Keywords: sandstones, heteroliths, ichnofossil, cores, depositional environment, Miocene

\section{Introduction}

The Niger Delta sedimentary basin (Fig. 1) is a low-gradient, delta plain-shelf wedge with an estimated areal extent of $300,000 \mathrm{~km}^{2}$ (Michele et al., 1999). The age of the delta ranges from Paleocene to Recent (Short \& Stäuble, 1965; Avbobvo, 1978; Doust \& Omatsola, 1990; Kulke, 1995; Michele et al., 1999). It lies in the Gulf of Guinea between the Calabar flank to the east and the Benin flank to the west and forms a passive divergent margin basin. It experienced slight lateral motion and wrench changes during the separation of the African and southern American plates. The delta progrades southwards onto the oceanic crust, initiated by the increased sagging of the crustal collapse under sedimentary load. Further accommodation for sediment accumulation was created by synsedimentary faulting within the delta sediments and lateral movement of prodelta deposits. The immense volume of sedimentary prism of the delta created its tectono-sedimentary environment and thus reservoirs for oil and gas accumulation. 


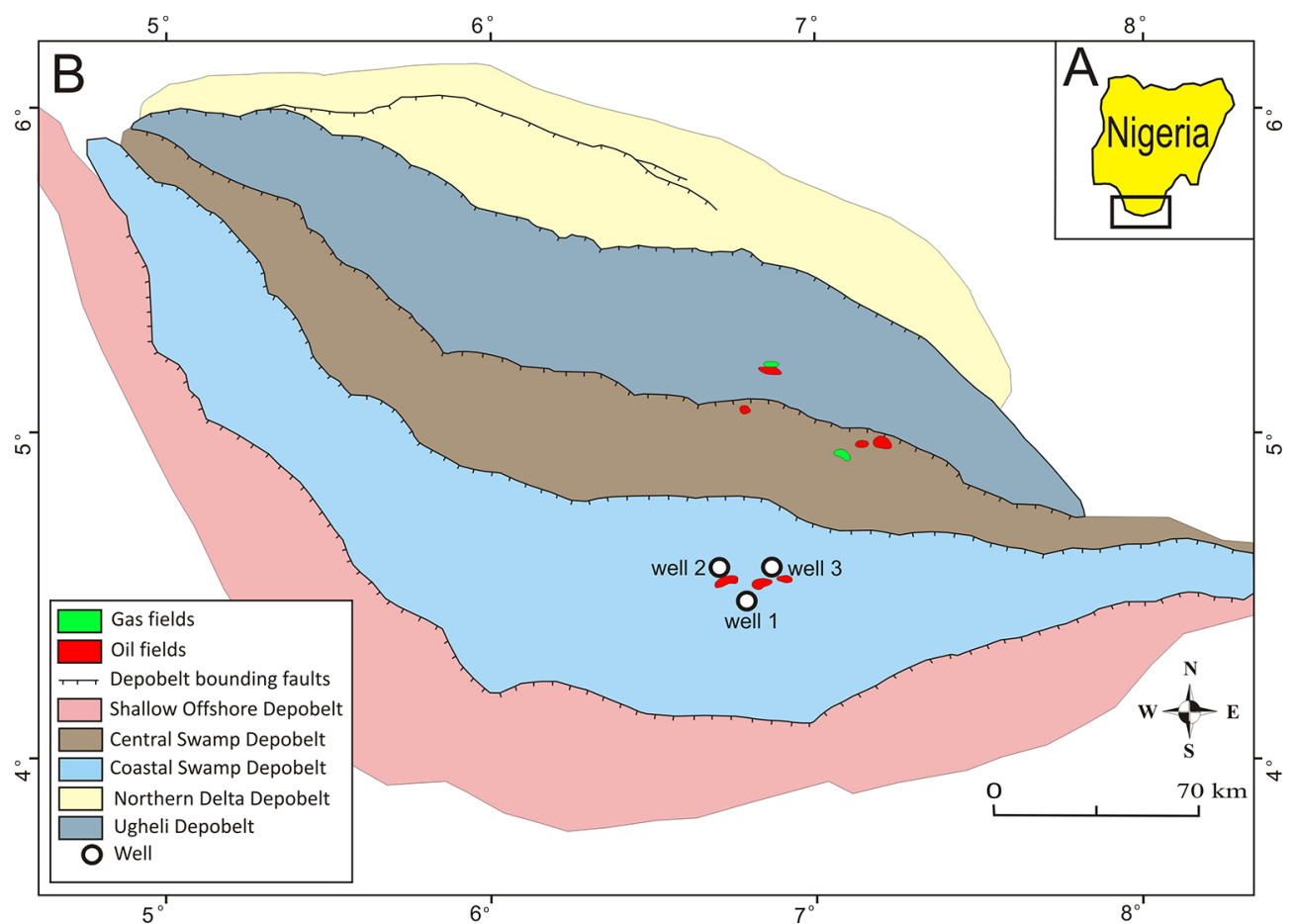

Fig. 1A - Map of Nigeria (insert) showing the Niger Delta depobelts (rectangular box); B - The Niger Delta Basin showing the wells (1-3) studied.

\section{Geological setting of the Niger Delta}

The Niger Delta ranks amongst the major regressive deltaic sequences in the world that is in its centre over $12,000 \mathrm{~m}$ thick and located in the Gulf of Guinea between longitude $5-8^{\circ} \mathrm{E}$ and latitudes $3-6^{\circ} \mathrm{N}$. The sedimentary sequence owes its origin to three main tectonic phases (Murat, 1970), coupled with transgressive and regressive marine pulses (Reijers, 2011). The Cretaceous section has not been penetrated beneath the Niger Delta Basin, the youngest and southernmost sub-basin in the Benue-Abakaliki trough (Reijers et al., 1997). The tectonic framework of the continental margin along the West Coast of equatorial Africa is controlled by Cretaceous fracture zones expressed as trenches and ridges in the deep Atlantic. The fracture zone ridges subdivide the margin into individual basins, and in Nigeria, this takes the form of boundary faults of the Cretaceous Benue-Abakaliki trough which cuts far into the West African shield. The trough represents a failed arm of a rift triple junction associated with the opening of the South Atlantic. In this region, rifting started in the Late Jurassic and persisted into the Cretaceous (Lehner \& De Ruiter, 1977).

The delta is divided into three diachronous formations, representing prograding depositional facies that are distinguished mostly on the basis of sand-shale ratios (Avbovbo, 1978; Doust \& Omatsola, 1990; Kulke, 1995). These are: (1) the oldest unit, the Akata Formation, is made up of prodelta shale with occasional turbidite sands. Beginning in the Paleocene and continuing to the Holocene, the Akata Formation formed during lowstands when terrestrial organic matter and clays were transported to deep-water areas characterised by low-energy conditions and oxygen deficiency (Stacher, 1995). It is estimated that the formation is up to 7,000 metres thick (Doust \& Omatsola, 1990). It underlies the entire delta, and is typically over-pressured. The thick shale of the Akata Formation, together with shale in the Agbada Formation, is the potential source rock of the delta; (2) the paralic Agbada Formation which comprises mainly shelf deposits of alternating sands and shale. This is the major petroleum-bearing unit of the delta. Its formation began in the Eocene and continues to the Recent. In the lower portion, shale and sandstone beds occur in equal proportions; however, the upper portion is mostly sand with only minor shale inter-beds (Michele et al. 1999); and (3) the youngest unit, the Benin Formation, is a continental uppermost Eocene to Recent deposit of alluvial and upper coastal plain sands that are up to 2,000 m thick (Avbovbo, 1978). Five main depositional belts, the Northern Delta, Greater Ughelli, Central Swamp, Coastal Swamp and Offshore Niger Delta (Fig. 1), are generally rec- 
ognised, each with its own sedimentary, deformational and petroleum history (Michele et al., 1999).

Two structural models have been proposed for the origin of the Niger Delta depositional belts (Doust \& Omatsola, 1990), namely the mobile shalelike salt model and the gravity model. Both models show very similar structural features, structural restoration and hydrocarbon charge results. Evidence for the mobile shale model includes numerous fluid expulsion features at the sea floor, particularly in deep water while the gravity slide model reveals that the shale portion is intact in the stratigraphical section. The depositional belts formed as the lowermost Cenozoic deltas loaded on the glide blocks. These glide blocks represent subsidence-laden sediment piles that moved basinwards to create accommodation space for the next depositional cycle. The repeated subsidence due to sedimentary load and the basinward shift of the deposits were conducive to the formation of synsedimentary faults within the sediment pile.

\subsection{The study area}

The study area (Fig. 1) lies between latitude $6^{\circ} 62^{\prime} 40^{\prime \prime}-6^{\circ} 95^{\prime} 11^{\prime \prime} \mathrm{E}$, and longitude $4^{\circ} 58^{\prime} 12^{\prime \prime}-4^{\circ} 65^{\prime} 15^{\prime \prime} \mathrm{N}$ in the central portion of the Coastal Swamp depobelt. Previous sedimentological works in the area focused on interpretation of the depositional facies using gamma ray well log signatures, usually without sedimentological core studies and trace fossil analysis. Only Egbu et al. (2009) applied ichnological analysis while examining ichnofacies and reservoir properties of shoreline deposits in the depobelt. They established five facies associations namely: foreshore, upper shoreface, proximal and distal middle shoreface, lower shoreface and offshore. In his stratigraphical and sedimentological studies of the Niger Delta Reijers (2011) used wireline log correlations and a number of features from core studies to interpret some activities in the Greater Ughelli depobelt. He noted that sea level rise triggered channel formation within the depobelt and destabilised adjacent shoreface sands. This rise was responsible for slumping and gravity transport that created the chaotic deposits within the channels. Omoboriowo et al. (2012), in the course of analysing the reservoir characterisation of the Konga field within the depobelt, used five gamma ray well log signatures from wells in the depobelt to infer environments of deposition. They used gamma ray well logs of one of the reservoirs to interpret the cylindrical (blocky) shape as fluvial/tidal floodplain or distributary channel, the funnel shaped (coarsening-upward pattern) as mouth bars/deltaic front or shoreface, saw teethed (serrated) shape as fluvio-deltaic plain/storm wave-dominated or distal marine slope, irregular blocky shaped as fluvio-deltaic plain/deltaic frontprodelta reworked offshore bars, and symmetrical hourglass (egg-shaped) as tidal flat-tidal channel fill/shoreface or proximal offshore (Fig. 2). Similarly, while determining the sequence stratigraphy of some Middle to Upper Miocene strata within the depobelt using gamma ray well log signatures only, Adegoke (2012) interpreted the cylindrical (blocky) shaped, funnel-shaped and bell-shaped as channel sands, barrier (beach) sands and shoreline-shallow marine environments, respectively. However, Pemberton et al. (1992) showed earlier that shallowwater and coastal marine environments comprises a multitude of sedimentological regimes, which were subject to large fluctuations in many physical and ecological parameters. In order to comprehend fully the depositional history of such zones in the rock record, it is imperative to have some reliable means of differentiating subtle changes in these parameters. In addition, detailed investigations in coastal marine zones of Georgia (USA) have shown the value of utilising biogenic sedimentary structures (in concert with physical sedimentary structures) in delineating these regimes (Frey \& Pemberton, 1987). Besides, information from gamma ray well log signatures does not capture some rock properties (e.g., grain size), but only the radioactive mineralogical composition of the strata. This means that interpretation from well logs alone can be misleading. In addition, well log signatures do not supply data on bioturbation and its impact on reservoir quality.

Here we make interpretations from gamma ray well logs of selected wells, coupled with analyses of cores and trace fossils from the same wells so as to obtain a reliable picture of depositional environments.

\section{Methods}

Detailed core descriptions (sedimentological and ichnological analyses) were made for three wells (Fig. 1) in different fields within the Coastal Swamp depobelt. Sedimentary features, associated trace fossils and bioturbation degree aided in classification of each deposit into lithofacies associations. The trace fossils observed were categorised into respective ichnofacies types based on Seilacher's model, as modified by Pemberton et al., (2001). Estimates of the degree of bioturbation (ichnofabric index) are based on the modified Droser and Bottjer's 


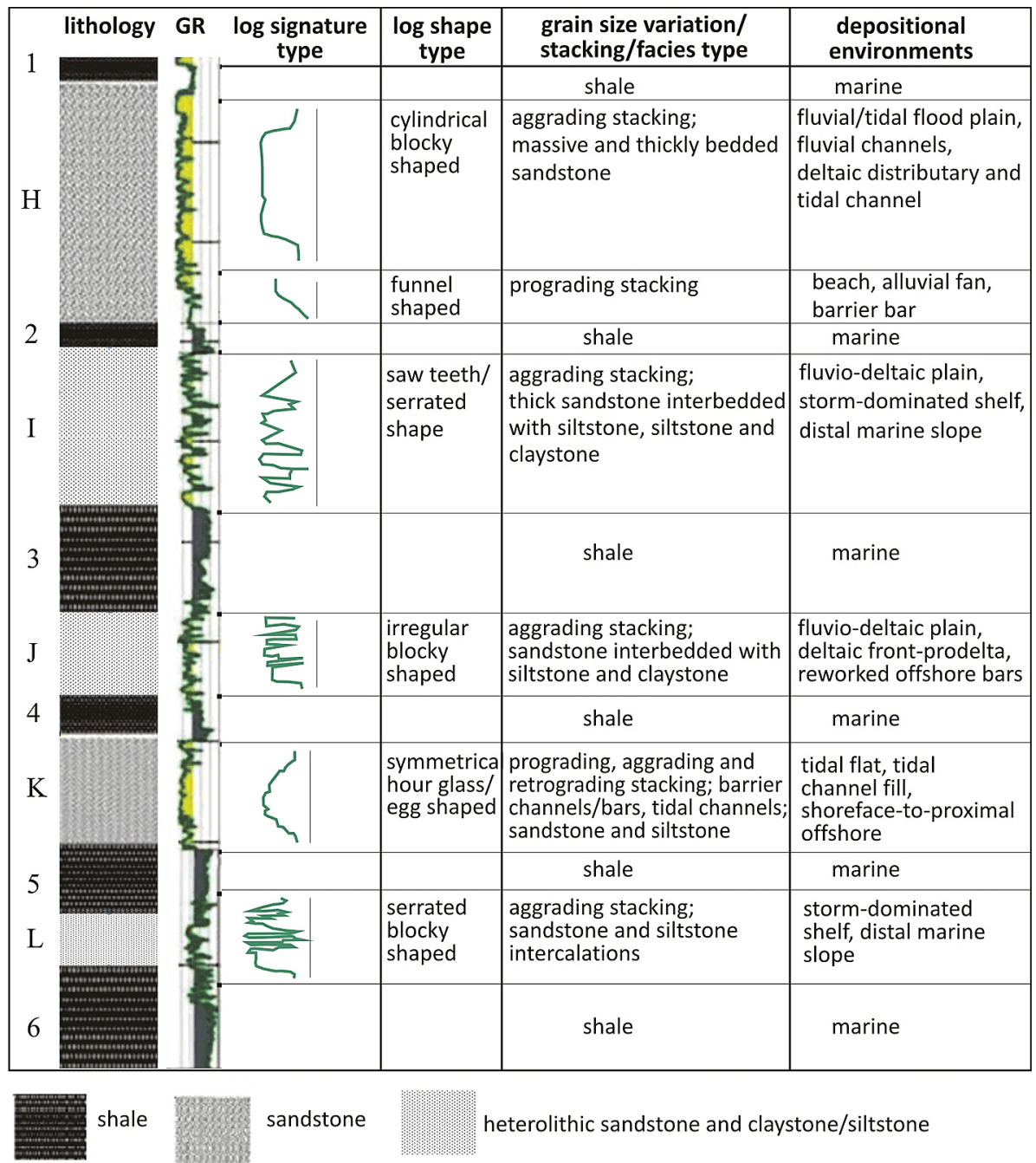

Fig. 2. Gamma ray log motifs of reservoir sands, their stacking patterns and depositional environments (after Omoboriowo et al., 2012).

ichnofabric index by Pemberton et al. (1992). Altogether, a total of $477 \mathrm{~m}$ was studied; in well 1,160 m was unrecoverable. The sedimentary descriptions and grain sizes obtained from the cores, together with gamma ray well logs for each well were put in Well CAD/CoreCAD to develop a lithostratigraphical section of the wells. The map of the study area was developed using ArGis Map 10. Depositional environment interpretation was made by integrating interpretations relied on a combination of sedimentological, ichnological and gamma ray well log features.

\section{Results}

The sedimentological, ichnological and gamma ray well log signatures of the well cores were used to define lithofacies from which are derived the depositional environments. These features are described in detail below for each of the wells.

\subsection{Lithofacies description}

Well 1 covered $185 \mathrm{~m}$ (with $160 \mathrm{~m}$ unrecovered) of amalgamated sandstone capped by mudstones and sandstones. Well 2 penetrated a 195-m-thick sequence of amalgamated sandstones capped by lower shoreface heteroliths, while well 3 comprises a 95-m-thick sequence of amalgamated sandstones overlain by mudstones and heteroliths. These facies were classified into six distinctive lithofacies, namely: cross-bedded sandstone, wave-rippled sandstone, current-rippled and muddy-sandy heteroliths, bioturbated mudstone, non-bioturbated mudstone and highly bioturbated muddy heteroliths. The details of these lithofacies are as follows:

\subsubsection{Cross-bedded sandstone (CS)}

The CS facies is subdivided into cross-bedded, medium-grained and cross-bedded, coarse-grained sandstones. The former is well sorted and Ophiomorpha predominates. Physical sedimentary structures 
are trough and tabular cross-bedding. Individual sets range from 15 to $30 \mathrm{~cm}$ in thickness, with planar to tangential trough cross-stratification dipping at angles of 15 to $25^{\circ}$. The surfaces of these non-erosive cross-beddings are bounded by double clay drapes (Fig. 3) and along the foresets of the crossbeds are laminae of carbonaceous plant detritus. Also present are tidal bundles and convolute beddings (Fig. 3B, E). No clay is found amongst sediment grains, except for the double clay drape laminae and the lined clayrich Ophiomorpha (Fig. 3D). In some sections Skolithos and Conichnus (Fig. 3F, E) have been recognised. The bioturbation index is 2 . The cross-bedded, coarsegrained sandstone consists of poorly sorted, randomly distributed pebbles (Fig. 3A) with bimodal sorting. The sorting is in the form of rhythmically alternating coarse-granular and medium-coarse grained foresets. Individual foresets are of $0.3-6 \mathrm{~cm}$ thickness and typically are normal graded (Fig. 3C). The clay component occurs as millimetre-thick foreset drapes. Heterolithic bottom sets are also locally developed, comprising thinly interbedded current-rippled sandstone and clay drapes. Clay drapes on foresets are typically single drapes. Trough cross-bedding is predominant, with subordinate tabular cross-bedding. Robust Ophiomorpha is common. The sequence occasionally fines upwards into a mudstone. In well 1 , Skolithos and Conichnus were absent and only a minor trace of Ophiomorpha type has been observed. However, other wells show a predominance of Ophiomorpha and only few examples of Skolithos and Conichnus.

\subsubsection{Wave-rippled sandstone (WS)}

The WS facies has been observed in well 2. It is characterised by well-sorted, fine to very finegrained sandstone with low clay content (less than 10 per cent). Physical sedimentary structures include erosively amalgamated sets of wave ripple cross lamination. Cross laminae display variable directions and degrees of asymmetry, symmetrical draping, chevron-up building, bundled up building, and opposed laminae directions within individual sets. No claystone or siltstone flasers and wavy beds have been observed.

\subsubsection{Current-rippled, muddy-sandy heteroliths (CRH)}

The CRH facies has been observed in well 2. It comprises very fine-grained, well-sorted sandstone interbedded with dark to pale grey siltstones and mudstones. It intermediates with the cross-bedded sandstone and possesses carbonaceous plant debris in the form of organic-rich laminae in the sands. Physical sedimentary structures are inclined heterolithic cross stratification, unidirectional current-ripple lamination, syneresis cracks (Fig. 4A) and load

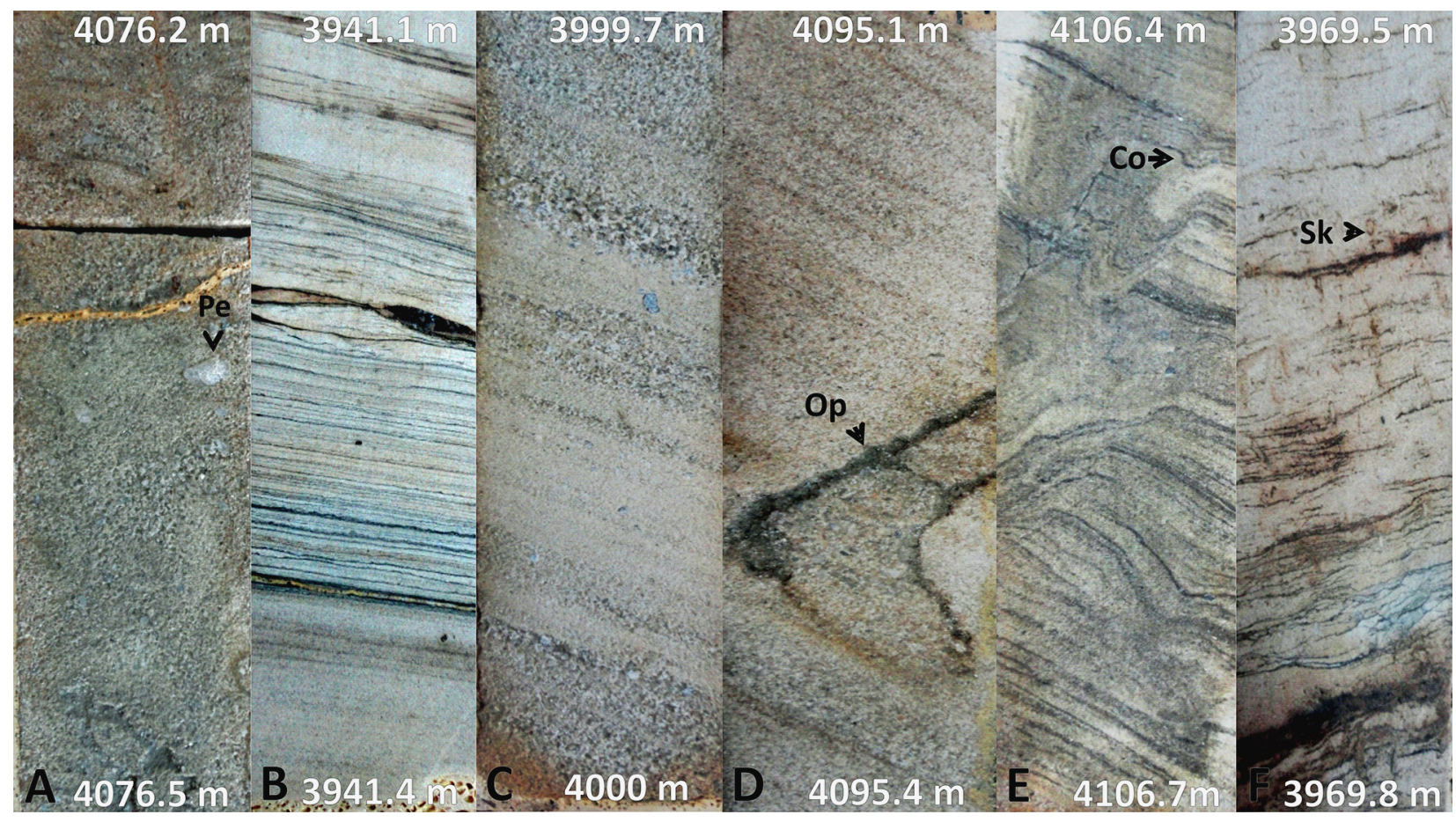

Fig. 3A - Cross-bedded, coarse-grained sandstone with random pebble (Pe) distribution; B - Double clay drape and tidal bundles in cross-bedded, medium-grained sandstone; C - Normal grading in the CS facies; D - Cross-bedded, coarse-grained sandstone showing the trace fossil Ophiomorpha (Op); E - Convolute bedding and the trace fossil Conichnus (Co); F - Skolithos (Sk)-dominated cross-bedded, medium-grained sandstone facies. 


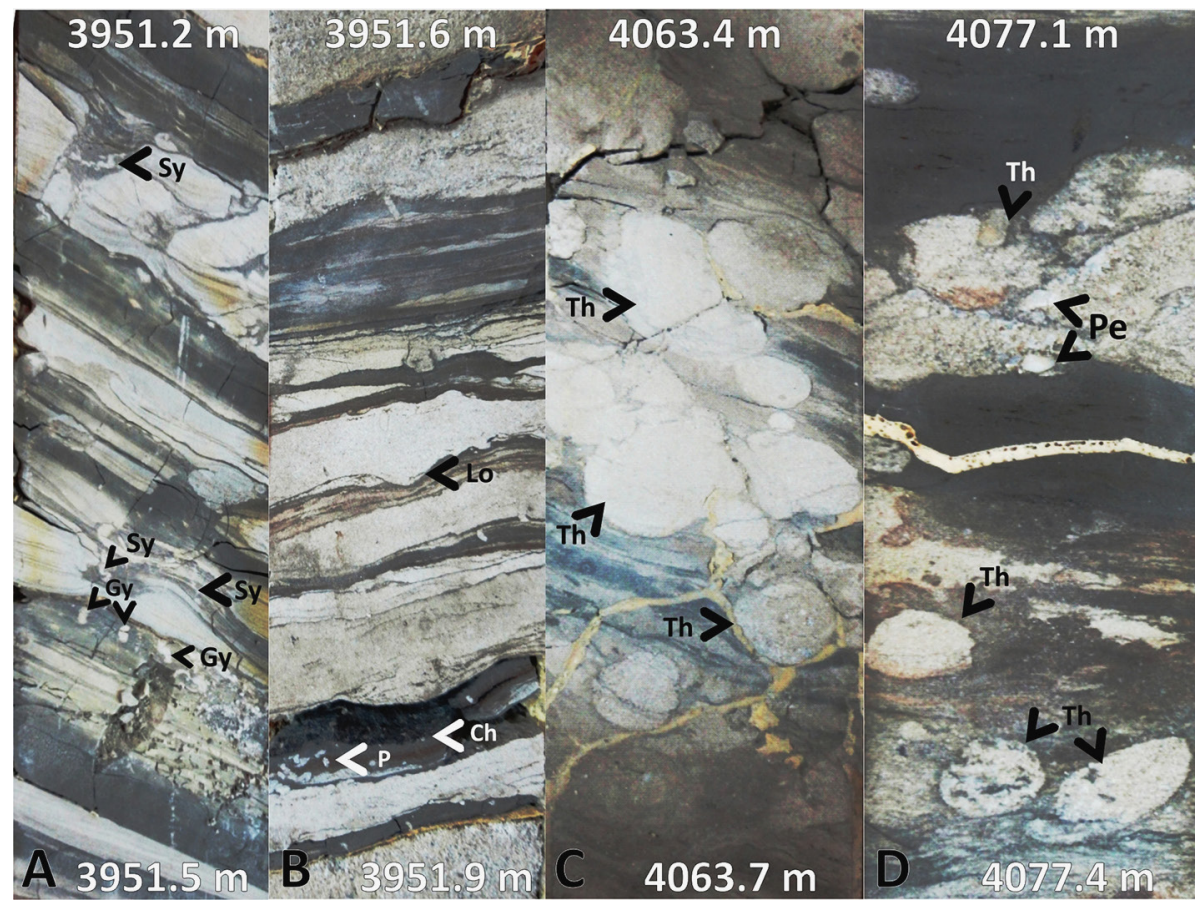

Fig. 4A - Gyrolithes-like traces (Gy) and syneresis cracks (Sy) within an inclined heterolithic, cross-stratified section; B - Planolites $(\mathrm{P})$, Chondrites $(\mathrm{Ch})$ and load structure (Lo) within the CRH facies; C, D - Thalassinoides (Th)-dominated BM facies. Note that the Thalassinoides infill consists of conglomeratic sands and pebbles $(\mathrm{Pe})$.

structures (Fig. 4B). The ripple-laminated sands, massive to laminated interbedded silts and clay are typically continuous. Common trace fossils are Gyrolithes-like traces (Gy), Planolites $(\mathrm{P})$ and Chondrites (Ch) (see Fig. 4A, B). The bioturbation index is 2.

\subsubsection{Bioturbated mudstone (BM)}

The BM facies has been documented in wells 2 and 3. It is fine-grained, reddish brown, very well-sorted, weakly laminated and dominated by Thalassinoides (Fig. 4C, D). Often, it caps the cross-bedded sandstone facies. The estimated bioturbated index is 4 .

\subsubsection{Non-bioturbated mudstone (NBM)}

This facies occurs as fine-grained deposits comprising shales and silty shales with a dark brown colour. Thin, horizontally bedded, planar and ripple cross-lamination, streaks and lenses of siltstone and very fine sandstone strata occur as well. The clay content is about 95 per cent. The claystones are massive to weakly laminated and sideritic in composition. Ripple beds are commonly discontinuous (lenticular ripple bedding). The estimated bioturbation index is 1 .

\subsubsection{Highly bioturbated muddy heteroliths (HBMH)}

This facies has been noted in wells 2 and 3 as highly bioturbated, mud-dominated heterolithic deposits, fine to very fine-grained and well-sorted sandstones, and claystones. The rarely visible physical sedimentary structures are remnants of centimetre-scale wave, current ripple, and planar laminated sandstones, siltstones and shales. Randomly distributed within the upper section are calcitic shell fragments (Fig. 5C), Schaubcylindrichnus (Fig. 5C), Asterosoma (Fig. 5A), Zoophycos-like trace (Fig. 5B), Rhizocorallium (Fig. 5B), Diplocraterion (Fig. 5A), Palaeophycus (Fig. 5A), Subphyllochorda (Fig. 5C) and Teichichnus (Fig. 5D). The estimated bioturbation index is 5 .

\subsection{Ichnological description}

The ichnofaunal assemblage of the coarse-gravelly sandstone of the CS facies in well 1 is rare; only a few Ophiomorpha were recognised. However, in other wells (2 and 3), this facies comprises robust Ophiomorpha, occasionally associated with Skolithos and Conichnus. The Ophiomorpha identified are typically vertical with few horizontal types. They attain lengths of up to $36 \mathrm{~cm}$ in length and widths of up to $3 \mathrm{~cm}$.

Unlike the CRH facies, the HBMH facies shows a dense set of a large and deeper-marine assemblage (Schaubcylindrichnus, Rhizocorallium, Asterosoma, Teichichnus, Thalassinoides and Subphyllochorda) that in most cases obliterate physical sedimentary structures of the facies. The ichnological assemblages are of moderate to great abundance and high diversity. The $\mathrm{CRH}$ facies shows a low-diversity, impoverished assemblage. 
Fig. 5A - Palaeophycus (Pa), Diplocraterion (Dp) and Asterosoma (As) within the highly bioturbated heteroliths; B - Schaubcylindrichnus (Sh), Rhizocorallium (Rh) and Zoophycos (Zo) in highly bioturbated heteroliths of well 2; C - Calcitic shell fragment (Ca), Subphyllochorda (Sc); D - Teichichnus (Te), Planolites (P) and Chondrites (Ch) in the $\mathrm{HBMH}$ facies.

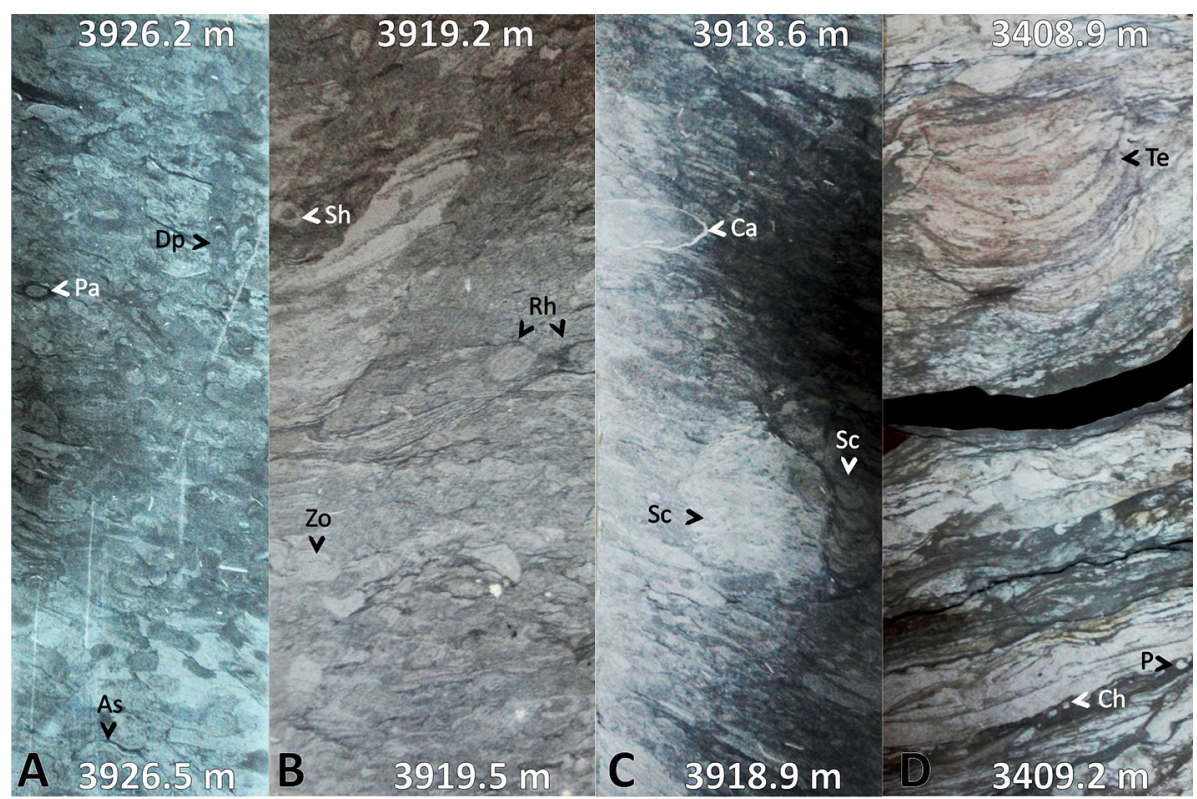

\subsection{Description of gamma ray well $\log (\mathrm{GR})$ signatures}

Gamma ray logs for sandstone usually read low, while for shale or claystone, they read high due to the radioactive elements present, although there are exceptions. For instance, feldspathic sands have relatively high gamma ray log reading due to the shaly nature or clay content.

The gamma ray well log signatures of the cross-bedded sandstone facies in well 1 is essentially cylindrical blocky (Fig. 6). In well 2, the basal section is characterised by a cylindrical (blocky) shaped gamma ray well log signature with a slight serration at a few points. The mid-section is bell shaped and followed by a serrated shaped signature. The lower section is cylindrical, the mid-section serrated-bell shaped and the topmost section cylindrical in shape (Fig. 7). In well 3, the basal section is characterised by irregularly blocky curve gamma ray well log signatures. At the top, sediments show a serrated and irregular blocky motif.

\section{Interpretation}

\subsection{Sedimentological and ichnological assessment}

The CS facies is interpreted as deposits of subaqueous dunes which formed under strong, lower-flow regime currents. The normal grading illustrates turbidity current. The coarse-grained character of the sediments indicates a fluvial source. The presence and thick lining of Ophiomorpha corroborate high-energy conditions related to continuous sand dune migration under marine or marginal-marine influence. Thin, millimetre-thick mud laminae and drapes point to deposition during brief low-energy periods, which allowed mud draping of the bedforms. Therefore, the CS facies is interpreted as having formed under high-energy conditions such as beach-line sections along the coast or tidal inlets as suggested by Boggs (1995).

The CRH facies comprises brackish-water deposits. A low-diversity, impoverished ichnofossil assemblage, and presence of syneresis cracks are common features within this setting (compare Wightman et al. 1987; Pemberton \& Wightman 1992; Buatois et al. 2005). The Chondrites-Planolites trace fossil suite in the lower half is common in brackish-water delta margin bays as outlined by Male (1992). Thus, the CRH facies is interpreted as brackish-water coastal marine heteroliths. However, the pervasively burrowed, heterolithic fabric of the HBMH facies indicates deposition in a low-energy, shallow-marine setting characterised by alternating bedload and suspension deposition. The trace fossil assemblage illustrates deposition in a fully marine setting such as a wave-dominated distal lower shoreface.

The NBM facies, which lacks ichnofossils, probably represents mud couplets associated with channel deposits, while the BM facies is consistent with open-marine shale deposited below effective storm wave base. The thin silt and sand beds are distal storm deposits. 


\subsection{Interpretation from gamma well log}

The cylindrical (blocky-shaped) gamma ray well log signatures for well 1 (Fig. 6) of the cross-bedded coarse-gravelly sandstone matches interpretations by Omoboriowo et al. (2012) and Adegoke (2012). Those authors interpreted the cylindrical gamma well log signatures to reflect channel sands. However, the cross-bedded, medium-grained sandstone exhibits a similar signature with the cross-bedded coarse gravelly sandstone (cylindrical/blocky shaped) instead of a coarsening-upward pattern (funnel shaped) as illustrated most commonly by shoreface deposits. This difference could be attributed to factors such as variation in the mineralogical composition. In addition, the gamma ray log response did not detect any differ- ence between sandstone and laminated mudstone, thinly bedded sections which were identified during the core description (note the gamma ray well log along the red boxes in Fig. 6). This could be due to $\log$ resolution.

Within wells 2 and 3, the blocky and serrated gamma ray well log signatures are consistent with our interpretation of sediment and trace fossil characteristics. These motifs illustrate fluvial and tidal channels. However, bell-blocky curves in well 2 (Fig. 7) that characterise shoreline-shallow marine settings are seen for sediments that were interpreted as lower shoreface heteroliths based on sediment and trace fossil characteristics. This kind of deviation could be due either to the type of measuring device or to mineralogical variation. In addition, the bell-shaped gamma ray well log signature that

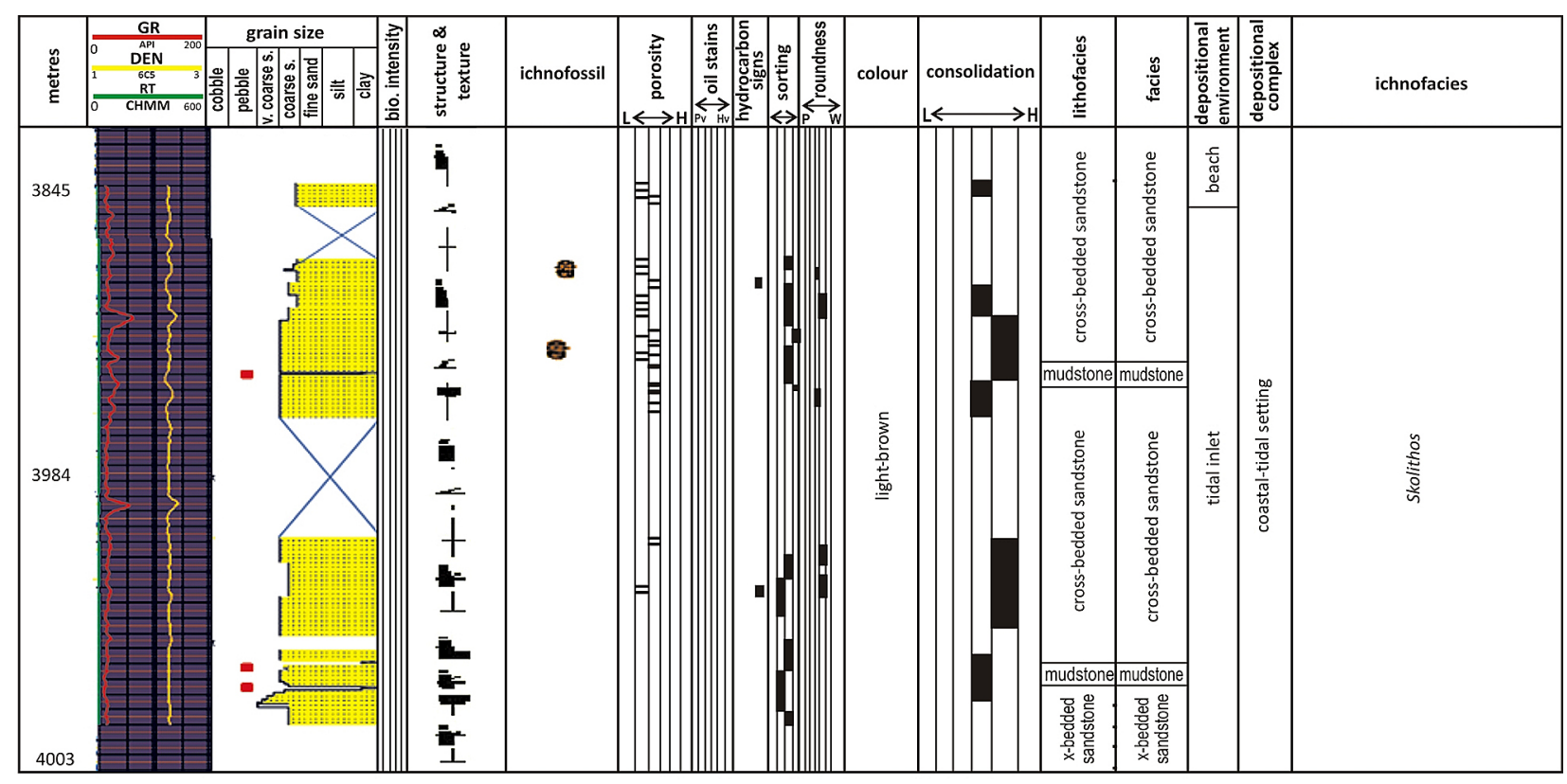

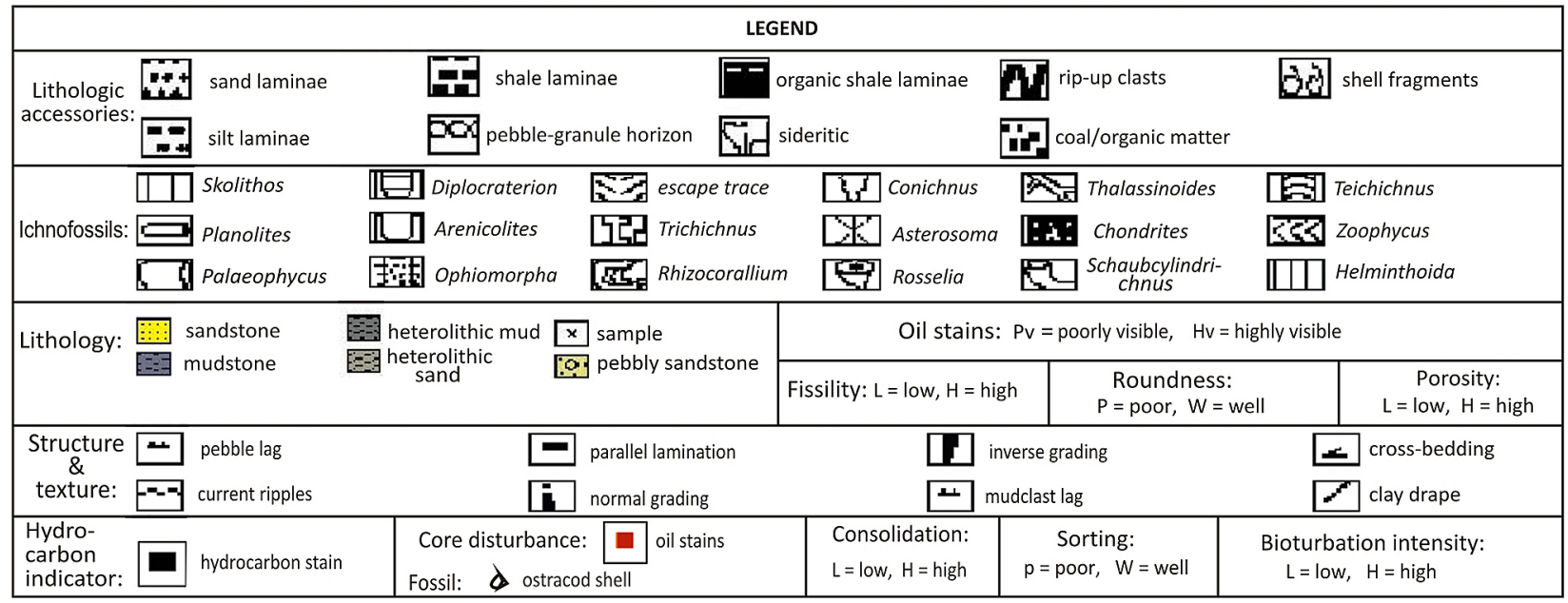

Fig. 6. Lithostratigraphical section of well 1. 


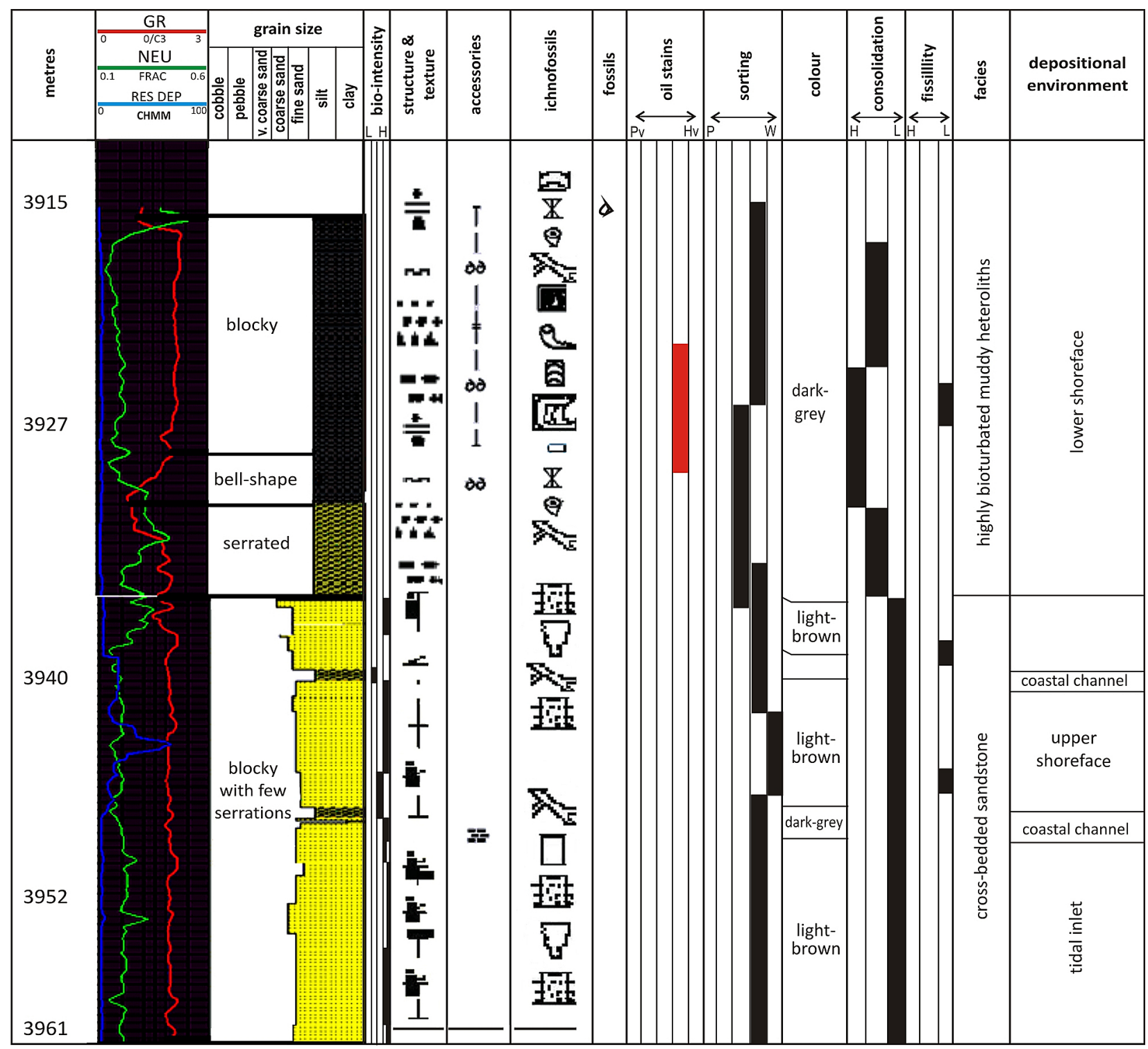

Fig. 7. Lithostratigraphical section of the upper unit in well 2.

would form in a shoreline-shallow marine environment occurs in a section here interpreted as coastal marine heteroliths based on sediment and ichnological characteristics (i.e., impoverished, low-diversity trace fossils assemblages). Such deviations reflect common limitations of gamma ray well logs in interpretations of depositional environments. Well 3 is characterised essentially by irregular blocky and serrated gamma ray signatures for tidal channels, rather than blocky types. Although the irregular blocky signature is consistent with Adegoke (2012), i.e., fluvio-deltaic deposits, the presence of serrated curves within the signatures could be misleading. This probably is the effect of mud couplets and clay drapes that are present in the sandstone (see sediment description above).

\section{Conclusions}

Although it is costly to obtain core data, the significance of cores to exploration and production cannot be overemphasized especially so in the prolific Niger Delta basin where there is no known outcrop. The risk of interpreting depositional environments solely on the basis of inferred data (seismic, electro facies, etc.) compared to direct observations is great. We may not be able to core all wells within a field, but our understanding derived from the study of cores from one or two wells in the same field will yield an idea of the depositional condition of surrounding wells within that field.

The present study further shows that electro-facies (e.g., gamma ray well log) interpretations may 
not always correspond to the actual depositional environment but that with data obtained from cores, this could be corrected. Secondly, it illustrates the significance of trace fossils in cores to interpretation of depositional settings. Thirdly, it documents the interwoven process of wave, river and tides during formation of Miocene sedimentary rocks in the Coastal Swamp depobelt of the Niger Delta. These processes affected the distribution of trace fossils which consequently are useful for interpretation. Lastly, core data from wells show that the strata in the study area reflect amalgamated channels in an estuarine environment, capped by deeper-marine deposits (lower shoreface heteroliths).

It is therefore recommended that interpretation of the depositional environment of subsurface sediments integrate all useful data (especially core data) in order to obtain a reliable result.

\section{Acknowledgements}

We wish to thank the Shell Petroleum and Development Company, Nigeria where the work was carried out especially the Geological Service team for their co-operation and assistance in the course of this research.

\section{References}

Adegoke, A.K., 2012. Sequence Stratigraphy of Some Middle to Late Miocene Sediments Coastal Swamp Depobelts, Western Offshore Niger Delta. International Journal of Science and Technology 2, 18-27.

Avbovbo, A.A., 1978. Tertiary lithostratigraphy of Niger Delta. American Association of Petroleum Geologists Bulletin 62, 295-300.

Boggs, S., 1995. Principles of Sedimentology and Stratigraphy. 2nd Ed. Prentice Hall, 774 pp.

Buatois, L.A., Gingras, M., Maceachern, J.A., Mangono, M.G., Zonneveld, J.P., Pemberton, S.G., Netto, R.G. \& Martin, A., 2005. Colonisation of brackish-water system through time: Evidence from the trace-fossil record. Palaios 20, 321-319.

Doust, H., \& Omatsola, E., 1990. Niger Delta. [In:] J.D. Edwards \& P.A. Santogrossi (Eds): Divergent/passive Margin Basins. American Association of Petroleum Geologists Memoir 48, 239-248.

Egbu, O.C., Obi, G.C., Okogbue, C.O. \& Mode, A.W., 2009. Ichnofacies and reservoir properties of shoreline deposit in Coastal Swamp Depobelt of the Niger Delta. AAPG Conference, Cape Town, 1-7.

Frey, R.W. \& Pemberton, S.G., 1987. The Psilonichnus ichnocoenose and its relationship to adjacent marine and non-marine ichnocoenoses along the Georgia coast. Bulletin of Canadian Petroleum Geology 35, 333-357.

Kulke, H., 1995. Nigeria. [In:] H. Kulke (Ed.): Regional Petroleum Geology of the World. Pt II: Africa, America,
Australia and Antarctica. Gebrüder Borntraeger, Berlin, 143-172.

Lehner, P. \& De Ruiter, P.A.C., 1977. Structural history of Atlantic Margin of Africa. American Association of Petroleum Geologists Bulletin 61, 961-981.

Male, W.H., 1992. The sedimentology and ichnology of the Lower Cretaceous (Albian)

Bluesky Formation in the Karr Area of West-Central Alberta. [In:] S.G. Pemberton (Ed.): Applications of Ichnology to Petroleum Exploration. Society of Economic Palaeontologists and Mineralogists Core Workshop 17, 33-55.

Michele, L.W., Tuttle, R., Charpentier, R. \& Michael, E.B., 1999. The Niger

Delta Petroleum System: Niger Delta Province, Nigeria, Cameroon, and Equatorial Guinea, Africa. U.S. Geologic Survey, $35 \mathrm{pp}$.

Murat, R.C., 1970. Stratigraphy and paleogeography of the Cretaceous and Lower Tertiary in Southern Nigeria. [In:] T.T.J. Dessauvagie \& A.J. Whiteman (Eds): African Geology. University of Ibadan Press, Nigeria, 251-266.

Omoboriowo, A.O., Chiaghanam, O.I., Chiadikobi, K.C., Oluwajana, O.A., Soronnadi-ononiwu, C.G. \& Ideozu, R.U., 2012. Reservoir characterization of Konga Field, Onshore Niger Delta, Southern Nigeria. International Journal of Emerging Technology 3, 19-30.

Pemberton, S.G. \& Wightman, D.M., 1992. Ichnological characteristics of brackish water deposits. [In:] S.G. Pemberton (Ed.): Applications of Ichnology to Petroleum Exploration. Society of Economic Palaeontologists and Mineralogists, Core Workshop 17, 141-167.

Pemberton, S.G., Frey, R.W., Ranger, M.J. \& Maceachern, J., 1992. Conceptual Framework of Ichnology. [In:] S.G. Pemberton (Ed.): Applications of Ichnology to Petroleum Exploration. Society of Economic Palaeontologists and Mineralogists, Core Workshop 17, 4-29.

Pemberton, S.G., Spila, M., Pulham, A.J., Saunders, T., Maceachern, J.A., Robbins, D. \& Sinclair, I.K., 2001. Ichnology and sedimentology of shallow to marginal marine systems: Ben Nevis and Avalon reservoirs, Jeanne d'Arc Basin. Geological Association of Canada, Short Course Notes 15, 343-349.

Reijers, T.J.A., 2011. Stratigraphy and sedimentology of the Niger Delta Basin. Geologos 17, 133-162.

Reijers, T.J.A., Petters, S.W. \& Nwajide, C.S., 1997. The Niger Delta Basin. [In:] R.C. Selley (Ed.): African Basins. Sedimentary Basin of the World. 3. Elsevier, Amsterdam, 151-172.

Short, K.C. \& Stäuble, A.J., 1965. Outline of geology of Niger Delta. American Association of Petroleum Geologists Bulletin 51, 761-779.

Stacher, P., 1995. Present understanding of the Niger Delta hydrocarbon habitat. [In:] M.N. Oti \& G. Postma (Eds): Geology of Deltas. Balkema, Rotterdam, 257-267.

Wightman, D.M., Pemberton, S.G. \& Singh, C., 1987. Depositional modelling of the Upper Manniville (Lower Cretaceous) Central Alberta: Discussion. Bulletin of Canadian Petroleum Geology 29, 622-625.

Manuscript received: 13 September 2015 Revision accepted: 20 July 2016 